\title{
Assessment of the Agronomic Feasibility of Bioenergy Crop Cultivation on Marginal and Polluted Land: A GIS-Based Suitability Study from the Sulcis Area, Italy
}

\author{
Giuseppe Pulighe ${ }^{1, *}$, Guido Bonati ${ }^{1}$, Stefano Fabiani ${ }^{1}$, Tommaso Barsali ${ }^{2}$, Flavio Lupia ${ }^{1}$, \\ Silvia Vanino ${ }^{1}$, Pasquale Nino ${ }^{1}$, Pasquale Arca ${ }^{3}$ and Pier Paolo Roggero ${ }^{3,4}$ \\ 1 Council for Agricultural Research and Economics-Centro di Ricerca di Politiche e Bioeconomia, Via Po 14, \\ Rome 00198, Italy; guido.bonati@crea.gov.it (G.B.); stefano.fabiani@crea.gov.it (S.F.); \\ flavio.lupia@crea.gov.it (F.L.); silvia.vanino@crea.gov.it (S.V.); pasquale.nino@crea.gov.it (P.N.) \\ 2 Biochemtex SpA, Strada Ribrocca 11, Tortona 15057, Italy; tommaso.barsali@gruppomg.com \\ 3 Department of Agricultural Sciences, University of Sassari, Viale Italia 39, Sassari 07100, Italy; \\ psarca@uniss.it (P.A.); pproggero@uniss.it (P.P.R.) \\ 4 Desertification Research Centre, University of Sassari, Viale Italia 39, Sassari 07100, Italy \\ * Correspondence: giuseppe.pulighe@crea.gov.it; Tel.: +39-06-4785-6814
}

Academic Editor: Robert Lundmark

Received: 14 July 2016; Accepted: 26 October 2016; Published: 31 October 2016

\begin{abstract}
In the context of environmental sustainability there has been an increasing interest in bioenergy production from renewable resources, and is expected that European biofuel production from energy crops will increase as a consequence of the achievement of policy targets. The aim of this paper is to assess the agronomic feasibility of biomass crop cultivation to provide profitable renewable feedstocks in a marginal and heavy-metal polluted area located in the Sulcis district, Sardinia (Italy). Results from literature review and unpublished data from field trials carried out in Sardinia were analysed to establish the main agronomic traits of crops (e.g., yield potential and input requirements). A Geographical Information System (GIS)-based procedure with remotely sensed data is also used to evaluate the land suitability and the actual land use/cover, considering a future scenario of expansion of energy crops on these marginal areas avoiding potential conflicts with food production. The results of the review suggests that giant reed, native perennial grasses and milk thistle are the most suitable energy crops for this area. The land suitability analysis shows that about 5700 ha and 1000 ha could be available for feedstock cultivation in the study area and in the most polluted area, respectively. The results obtained from land suitability process and agronomic evaluation will serve as a base to support technical and economical feasibility studies, as well as for the evaluation of environmental sustainability of the cultivation in the study area.
\end{abstract}

Keywords: agronomic feasibility; geographic information system (GIS); spatial analysis; biomass; land suitability; marginal land

\section{Introduction}

In recent years, there has been an increasing interest in a low-carbon society, where the use of biomass as feedstock to produce renewable energy, bio-based chemicals and bio-fuels is a promising alternative to non-renewable fossil resources $[1,2]$. The production of bioenergy from renewable feedstocks is being encouraged by the European Union (EU) and national legislations in order to address a number of environmental and societal issues, like reduction of greenhouse gases emissions, energy security, competition with food production and loss of ecosystem functions and services [3-5]. 
The biomass feedstocks produced by dedicated crops are expected to develop alternative systems of energy production and markets, promote rural development and livelihoods and revive economic growth. For example, a recent study by the Unated Sstates Department of Agriculture (USDA) reports that the biobased products industry contributed $\$ 369$ billion and 4 million jobs to the Unated States economy in 2013 [6], while the European bio-based industry contributed with 3.2 million employees in 2013 [7].

In order to avoid competition and controversies between food and energy crops, the potential use of less productive and marginal land for bioenergy production has been proposed worldwide [8,9]. Marginal and degraded land can be defined as land less suitable or totally unsuitable for food production where a low level of economic profit is expected [10]. Marginal lands could be correctly identified and valued with a land suitability analysis based on multi-criteria approaches which enable to integrate environmental constraints (e.g., soil depth, erosion, slope) [11] and social and economic needs of the communities engaged [12,13].

In this framework, the development of lignocellulosic production systems (also known as 'second-generation' production technology) on marginal land has attracted attention from researchers, policy makers and the EU as promising and viable renewable biomasses for the production of high added value biofuels and bioproducts [4] that minimizes competition with food production [14]. Second-generation biofuels are produced from cellulose, hemicelluloses or lignin derived from herbaceous energy crops, crop residues and woody crops [15]. Feedstocks for second-generation biofuels have the potential to complement intensive agriculture, require lower energy input and produce lower environmental impacts than conventional feedstocks [16]. Furthermore, the cultivation of lignocellulosic crops on contaminated land prevents of toxic heavy metals and organic pollutants leaching through the process of phytostabilization [17-19], reduces environmental contamination, decreases human exposure to contaminants and their transfer into the food web and increases the environmental security of polluted habitats. However, the cultivation bioenergy of crops on marginal land and lower grade soils would require the evaluation and comparison on realistic yield expectations and agronomic management practices. The need to account for agroecological constraints (e.g., suitable species, water footprint, use of fertilizers, productivity) imposes a sustainability agronomic assessment to identify bottlenecks, burdens, limitations and benefits before agricultural management is upscaled from field trials to regional scale.

Against this background, the main objective of this study is to assess the agronomic feasibility of bioenergy feedstock cropping systems with a multi-criteria land suitability analysis in a Mediterranean district located in the Sulcis area of Sardinia. In this area, due to soil and water pollution generated by human-dominated processes (i.e., former industrial sites and abandoned mines and quarries), large portions of the district can now be considered marginal lands, thus representing an interesting case to test the feasibility of the integration of non-food cropping systems.

The study comprised three major steps: (i) development of a comprehensive database on bioenergy crops based on literature data and field trial results; (ii) comparison of agronomic characteristics and biomass yield potential for transferable value chains; (iii) geographic information system (GIS)-based evaluation on marginal and polluted land potentially suitable for biomass production within existing land use/cover patterns in Sardinia. The outcome of this case study strives to provide new insights into agronomic and methodological implementation of bioenergy crops at large scale in marginal areas, it also provide useful spatially explicit information for bio-energy developers, scholars and policy makers in the energy and in the agricultural sector.

\section{Materials and Methods}

\subsection{Description of the Study Area}

The case study area is the Sulcis district located in the South-west Sardinia, Italy $\left(39^{\circ} 09^{\prime}\right.$ North latitude, $8^{\circ} 29^{\prime}$ West longitude, city of Carbonia, Figure 1). It is characterized by a flat and undulating 
topography which extends from the coastline to inland rugged areas, with elevation ranging from 1 to $450 \mathrm{~m}$ above mean sea level (a.m.s.l.). The climate of this area is between semi-arid and dry sub-humid [20], with the typical bimodal pattern of precipitation distribution (i.e., maximum in autumn and spring).

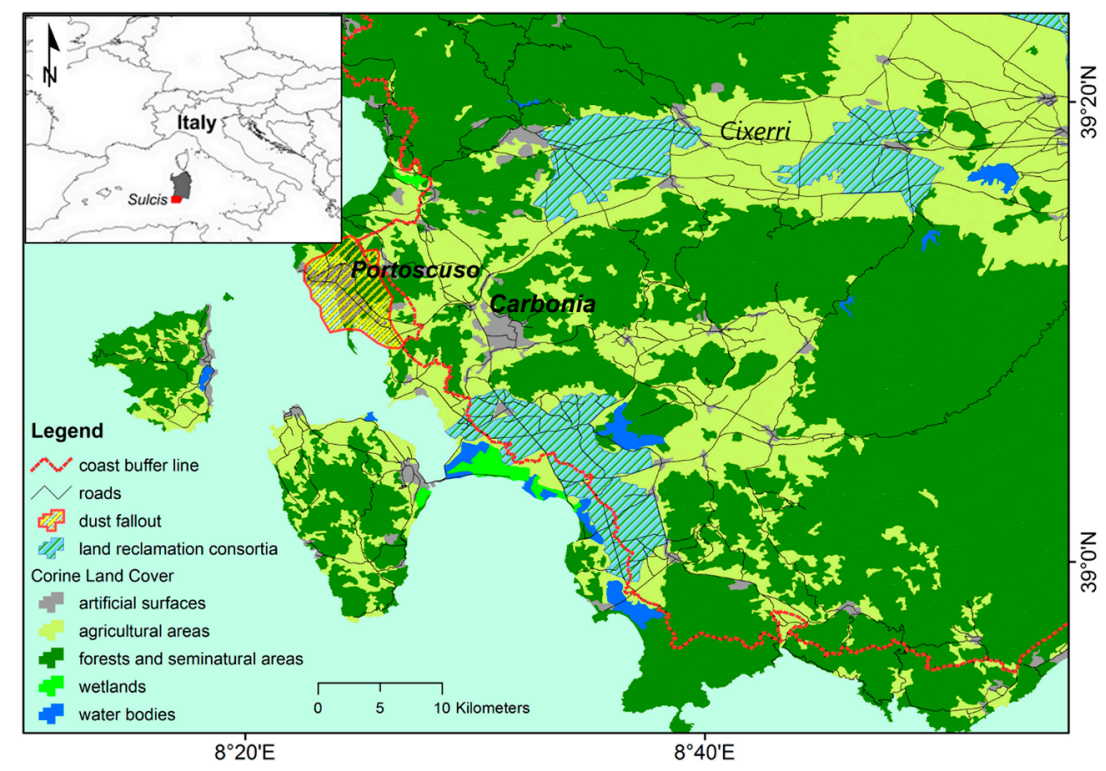

Figure 1. Map of the study area. Representation with Corine Land Cover 2012 at first level of nomenclature (five classes).

Average annual rainfall is about $550-600 \mathrm{~mm}$ and annual mean temperature is $16{ }^{\circ} \mathrm{C}$. The soil types of the agricultural land are mainly Xerofluvents (Petric Calcisols; Haplic Nitosols; Calcic Luvisols), Chromoxererts (Vertic and Eutric Cambisols) and Xerochrepts (Eutric, Calcaric and Mollic Fluvisols) [21]. The land use is mainly represented by arable land over flat terrain, to a lesser extent vineyards, Mediterranean grasslands and Eucalyptus plantations on non-arable land, with forest vegetation over rugged terrain. The coastal area is considered an environmental sensitive and ecologically protected region and hosts endangered aquatic and terrestrial species.

The study area is located in the largest Contaminated Sites of National Interest (SIN) in Italy (about 22,000 ha), polluted by heavy metals (mainly Pb, Cu, Cd, Co and $\mathrm{Zn}$ ) from industrial flumes derived from coal power generation, bauxite and aluminum production, as well as by the centuries-old previous mining activities. In the past, considerable emissions into the atmosphere were estimated annually up to 65,000 $\mathrm{t}$ of sulphur oxides, $4000 \mathrm{t}$ of dust, $10 \mathrm{t}$ of $\mathrm{Pb}$ and $100 \mathrm{t}$ of Fe [22]. In addition, heavy metal pollution is also evident in the shorefront the city of Portoscuso and in the Portovesme harbour. A study on the marine sediments showed highest values of $\mathrm{Pb}$ (up to $117.9 \mu \mathrm{g} / \mathrm{g}$ dry weight (d.w.)), Zn (up to $668.5 \mu \mathrm{g} / \mathrm{g}$ d.w.), Cr (up to $44.7 \mu \mathrm{g} / \mathrm{g}$ d.w.) along with relevant levels of polycyclic aromatic hydrocarbons ( $>5000 \mathrm{ng} / \mathrm{g} \mathrm{d.w.)}$ in the first $3 \mathrm{~cm}$ of sediment [23].

In the municipality of Portoscuso, contaminated by dust fallout of the surrounding industrial area (see Figure 1), the topsoil $(0-10 \mathrm{~cm})$ and groundwater values of pollutants in the monitoring network (e.g., $\mathrm{Hg}$, Se, Pb, Fe, Zn, As, sulfates and fluorides) exceed the legal thresholds [24]. For example, the values of $\mathrm{Pb}$ and $\mathrm{Cd}$ in some sampling stations in the period 2009-2014 have reached $\sim 3500 \mathrm{mg} / \mathrm{kg}$ and $\sim 40 \mathrm{mg} / \mathrm{kg}$, respectively. In this municipality the cultivation and commercialization of agricultural goods and milk production are forbidden due to the potential threat to human health [25]. A recent study by Varrica et al. [26] on toxic metals in hair samples of children living near mining tailings of Sulcis-Iglesiente district (Carbonia and Iglesia, Italy), reports potential health risks for the exposed population. 


\subsection{Data Collection and Crops Comparison}

The successful implementation of energy crops as an integral part of traditional production system is a difficult task that requires an accurate agronomic evaluation in terms of environmental adaptability, productivity, logistics, restricting factors and synergies with crop rotation schemes.

A considerable amount of literature has been published worldwide about biomass production potential of dedicated energy crops [27-29]. However, most of these studies investigated only one or a few crops on a small number of sites, which make it difficult to compare the most studied bioenergy crops [30,31]. In addition, considerable differences in the agronomic management related to soil and climate conditions between studies worldwide and the specific Mediterranean conditions of Sardinia are serious drawbacks for the correct comparison and ranking of crops biomass yields.

In order to identify the most suitable biomass feedstocks and understand the implications for crop management, in this study only the relevant results from scientific studies and field trials on bioenergy crops conducted in Sardinia were collected and analysed. The data were obtained using the ISI Web of Science databases and Google Scholar to search for published paper containing terms like 'bioenergy', 'biomass', 'crop', 'feedstock', 'lignocellulosic', 'energy' and 'Sardinia' in titles, abstracts or keywords.

The search was carried out selecting original articles published in English and in Italian in peer-reviewed journals, conference abstracts, technical reports, books and dissertations, prioritizing works that explicitly report field-based experiments, details on the cultivation techniques and yield data. References reported in the identified papers were also checked. In-depth evaluation of the most relevant studies allowed to extract relevant data from text and tables. Regarding other common biomass crops such as sunflower, poplar and robinia, there are no papers or field trials available, since these species grow better on temperate climates and are not suitable for the agro-climatic conditions of Sardinia. Moreover, the results from field trials carried out by Biochemtex SpA in collaboration with the Desertification Research Centre and the Department of Agricultural Sciences of the University of Sassari were combined with relevant informations from the literature and collected in a relational database.

All these findings were analysed considering cultivation protocols, crop requirements and site-specific conditions that can influence biomass yields and composition during the growing season (i.e., potential yield, dry matter content, cultivar, content of fermentable sugars, irrigation and fertilisation requirements, adaptation to soil texture and $\mathrm{pH}$, elevation, length of growing seasons). Reporting precise geo-referenced field trial data will allow in the future to test plant-growth models and empirical estimates.

The output of this analysis is a short list of bioenergy crops that could be cultivated under the study area conditions. All relevant data extracted and examined were implemented in a relational database, following the structure recently implemented by Lauent et al. [31]. Table 1 summarizes the crops analysed, differentiated by typology of use in herbaceous (annual and perennial) and woody crops.

Table 1. Summary of the different typologies of biomass crops analysed. In brackets the number of studies.

\begin{tabular}{|c|c|c|c|}
\hline \multirow{2}{*}{ Typology } & \multicolumn{2}{|c|}{ Herbaceous Plants } & \multirow{2}{*}{ Woody Plants } \\
\hline & Annual & Perennial & \\
\hline $\begin{array}{l}\text { Lignocellulosic } \\
\text { crops }\end{array}$ & $\begin{array}{l}\text { Globe artichoke (Cynara cardunculus L. var. } \\
\text { scolymus })(n=3) \\
\text { Milk thistle (Silybum marianum L. Gaertn.) } \\
(n=4)\end{array}$ & $\begin{array}{l}\text { Cardoon (Cynara cardunculus L. var.altilis) }(n=5) \\
\text { Giant reed (Arundo donax } \text { L.) }(n=4) \\
\text { Miscanthus (Miscanthus } \times \text { giganteus Greef et Deuter) } \\
(n=1) \\
\text { Switchgrass (Panicum virgatum L.) }(n=1) \\
\text { Smilo grass (Piptatherum miliaceum }(\text { L.) Coss.) }(n=1) \\
\text { Tall fescue (Festuca arundinacea Schreb.) }(n=2) \\
\text { Ryegrass (Lolium perenne L.) }(n=1) \\
\text { Cocksfoot (Dactylis glomerata L.) }(n=2)\end{array}$ & $\begin{array}{l}\text { Eucalyptus (Eucalyptus spp.) } \\
(n=2)\end{array}$ \\
\hline
\end{tabular}


Table 1. Cont.

\begin{tabular}{|c|c|c|c|}
\hline \multirow{2}{*}{ Typology } & \multicolumn{2}{|c|}{ Herbaceous Plants } & \multirow{2}{*}{ Woody Plants } \\
\hline & Annual & Perennial & \\
\hline Oilseed crops & $\begin{array}{l}\text { Rapeseed (Brassica napus L.) }(n=2) \\
\text { Ethiopian mustard (Brassica carinata A. } \\
\text { Braun) }(n=2)\end{array}$ & & \\
\hline Sugar crops & $\begin{array}{l}\text { Sweet sorghum (Sorghum bicolor (L.) } \\
\text { Moench) }(n=2)\end{array}$ & & \\
\hline Starch crops & $\begin{array}{l}\text { Maize (Zea mais L.) }(n=3) \text {; } \\
\text { Durum wheat (Triticum durum Desf.) }(n=2) \\
\text { Triticale }(x \text { Triticosecale })(n=3)\end{array}$ & & \\
\hline
\end{tabular}

\subsection{Identification of Suitable Land}

In order to accurately spatialize the suitable land for the cultivation of energy crops, a series of georeferenced data were identified, collected and organized with an ArcGIS ${ }^{\circledR}$ geodatabase (Esri, Redlands, CA, USA). The data-sets used for the spatialization process were as follows: Digital Elevation Model (DEM), soil type map, land use/cover map, climate data and administrative boundaries (Table 2). The methodological framework follows a multi-criteria decision making approach by considering diagnostic criteria based on the literature review and results of field trials. A large and growing body of literature has investigated the use of GIS for multi-criteria land feasibility analyses of bioenergy crop systems [32-34]. See for instance Lewis and Kelly [35] for a comprehensive analysis on definitions, data and models used for mapping bioenergy crop potential on marginal lands.

Table 2. Data sources used in the GIS-based suitability analysis.

\begin{tabular}{ccccc}
\hline Input Data & Resolution & Constraints & Data Source & Ref. \\
\hline Land use/cover & $\sim 1: 10,000$ & orchards, forestry & CREA & - \\
Corine Land Cover & $1: 25,000$ & orchards, forestry & EEA & {$[36]$} \\
Natural and protected areas & $1: 10,000$ & whole areas & RAS & {$[37]$} \\
Restricted and polluted areas & $1: 10,000$ & whole areas & RAS & {$[37]$} \\
Soil data & $1: 250,000$ & 1st-2nd capability class & RAS & {$[37]$} \\
DEM (slope) & $10 \mathrm{~m}$ & $>5$ th capability class & RAS & {$[37]$} \\
Meteorological data & $\sim 1 \mathrm{~km}$ & $<300 \mathrm{~mm} \cdot$ year $^{-1}$ & WorldClim & {$[38]$} \\
(precipitation, temperature) & $1: 10,000$ & $<15^{\circ} \mathrm{C} \cdot$ year $^{-1}$ & RAS & {$[37]$} \\
Hydrography & $1: 10,000$ & $150 \mathrm{~m}$ buffer & RAS & {$[37]$} \\
Roads & $1: 10,000$ & $\sim 2500 \mathrm{~m}$ buffer & RAS & {$[37]$} \\
Coast line & $1: 10,000$ & $150 \mathrm{~m}$ buffer & RAS & {$[37]$} \\
Built-up areas & $1: 10,000$ & - & CREA & {$[39]$} \\
Irrigation and land & & & & \\
reclamation borders & & & &
\end{tabular}

Notse: DEM-Digital Elevation Model; CREA-Council for Agricultural Research and Economics; EEA-European Environment Agency; RAS-Autonomous Region of Sardinia.

In view of environmental sustainability, in this study we applied very restrictive and precautionary constraints in terms of environmental factors (i.e., soil, water, flora and fauna, biodiversity and landscape). In fact, the conversion of marginal land to bioenergy cropping system is a decision driven by the interaction of multiple natural and human driving forces [40] with inevitable trade-offs between natural resources and their use [13].

In this regard, the conversion of traditional cropping system to large scale bioenergy plantations might potentially affect soil properties, hydrologic processes and nutrient cycling, which may result into undesirable environmental side effects [41]. Furthermore, marginal and degraded lands can be rich in biodiversity and hotspots for vulnerable and endangered species [42,43], thus a conservative landscape management approach could contribute to mitigating the impacts of land use change. 
According to these planning rules, a buffer distance was defined in order to protect the natural features from dissemination of seeds, pollen and sprouts, boost biodiversity, as well as to ameliorate the visual impact on the aesthetic values of the landscape. Similarly, Miyake et al. [44] identified a buffer zone of $200 \mathrm{~m}$ from water and natural areas to avoid the possibility of seed dispersal on the conversion of underutilized marginal land in a case study region in subtropical Queensland, Australia. Combining research findings with scholars observations [45-47], soil slope $>10 \%$ was deemed unsuitable considering problems for machinery operations and soil erosion risk.

Furthermore, we follow the outcomes of Angelini et al. [28] that for perennial rhizomatous grasses cultivation (i.e., giant reed and miscanthus) in Mediterranean agricultural areas suggested useful rain not less at $300 \mathrm{~mm}$ and at least 1800 growing degree days. Meteorological data were acquired from WorldClim [38], regional data were provided by 'Agenzia Regionale per la Protezione dell'Ambiente della Sardegna' (ARPAS) and Autonomous Region of Sardinia (RAS) [37], land use was obtained by the Corine Land Cover database, provided by European Environment Agency (EEA) [36]. All data are available for free download. Data on Irrigation and Land Reclamation Consortia (ILRC) were supplied by Council for Agricultural Research and Economics (CREA) [48]. GIS-based methodology developed to estimate land suitability is illustrated in Figure 2. In order to ensure the profitability of a biomass commodity chain considering a logistics management [49,50], we hypothesize a maximum cultivation distance of about $70 \mathrm{~km}$ from a hypotetical biorefinery located in the most contaminated area of Portoscuso.

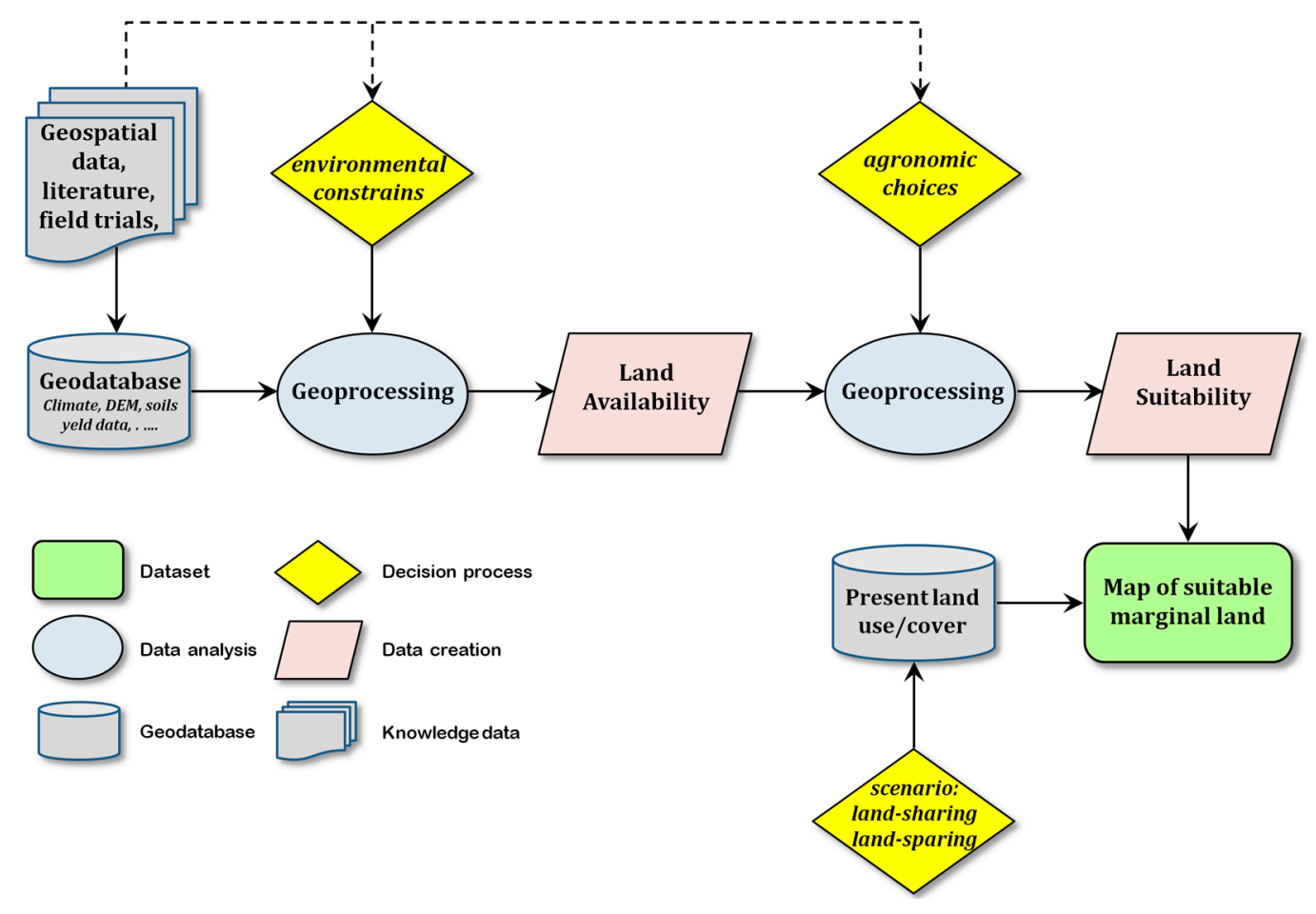

Figure 2. Flowchart illustrating the methodology developed to estimate the land suitability for bioenergy crops.

The procedure is structured in two phases. The first phase aims to identify the availability map, consisting of an exclusion approach derived from environmental, topographic and climatic constraints, as a result of specific potentials and limitations of the bioenergy crops evaluated. The second phase aims to derive the suitability map, as a result of agronomic and economic choices made to avoid the competition and conflict with food crops. In order to respect minimum environmental requirements, the Renewable Energy Directive [51] and the Italian legislation actually limit the cultivation of 
dedicated crops for biofuels production in land with high biodiversity value (i.e., primary forest and other wooded land, designated areas, highly biodiverse grassland).

Firstly, slope, precipitation and temperature maps were calculated, reclassified and converted in vector format applying the constraints listed in Table 2. As a result, areas not fulfilling all constraints were scored 0 in the attribute table and are fully excluded in the following analyses, otherwise the score was set to 1 if all constrains are met, and therefore these areas are fully included in the following analyses. Secondly, buffer zones were defined and calculated around residential areas, major roads, rivers and lakes, restricted areas and polluted areas, restricted coast line, natural and protected areas, orchards and forest plantation derived from Corine Land Cover 2012 were also excluded from the analysis. All these areas were geometrically merged and dissolved and excluded in the analysis (score 0). Thirdly, buffer zones were erased from the areas scored 1 in the first step, subsequently a geometric union with the soil map was performed. Furthermore, in this output land capability classes higher than the fifth level (soils with severe limitations suitable only for grazing, reforestation and restoration) were scored 0 in the attribute table, while the remaining classes from the first to fifth were scored 1 , and therefore included in the following phase.

This final data represent the availability map. The land suitability map is the result of agronomic choices that restrict bioenergy crops to marginal and less productvive soils (land capability classes III, IV and V-soils having severe limitations that restrict their use or require careful management), thus excluding the best and highly productive soils (land capability classes I and II-soils have slight or moderate limitations that restrict their use), consistently to what suggested by Tenerelli and Carver [52] and Miyake et al. [44] for the land allocation modelling of perennial energy crops.

\subsection{Actual Land Use/Cover}

In this study an attempt was made to investigate existing land use/cover within the ILRC 'Cixerri', an important agricultural irrigation district in the Sulcis area (about 9180 ha). The detection of the actual cultivation pattern (especially irrigated areas and orchards) is accomplished through a 'multi-temporal analysis' based on a time series of the Normalized Vegetation Index (NDVI) derived from satellite images (i.e., Landsat- 8 Operational Land Imager (OLI)). The NDVI time series provide the temporal evolution of the crops and vegetation during its growing season. The methodology is based on the assumption that in arid and semi-arid environments high rates of vegetation growth are compatible only with irrigation [53]. The temporal pattern recognition based on the differences from the canopy cover and development was pivotal to assign each pixel to a vegetation class. Overall, the following eight classes were identified: (1) irrigated arable land; (2) non irrigated arable land; (3) orchards; (4) olive trees; (5) vineyards; (6) urban area; (7) woodland; (8) water. The procedure requires basic knowledge of crops and their phenology and a subsequent validation by an experienced operator of the study area. Moreover, additional information like orthophotos and existing land use/cover databases are necessary for interpreting some irrigated crops such as fruit trees, vineyards or olive trees with limited canopy growth. For this reason recent orthophotos were used as geometric reference, while the infrared images and NDVI time series supported the thematic photo-interpretation and parcel delimitation.

The land suitability map and the actual land use/cover map were used to assess a potential scenarios for biomass supply chains based on the actual land framework with a comparison of a land-sharing versus land-sparing cultivation strategy [54]. The analysis was done within the ILRC 'Cixerri' by subtracting from land suitability map the land use/cover layer constraints. The land-sparing options promoted intensification and specialization of agriculture activities, where all available arable land are converted for feedstock production, with a separation of protected habitats to foster biodiversity conservation. Conversely, land-sharing promotes an integration of traditional crops with buffer corridors and natural habitats for a more heterogeneous landscape [55]. Overall, the integrated landscape management with the optimal allocation of land resources among food 
production, feedstock production and ecosystem protection should minimize the competition and increase the farming sustainability over the long run.

\section{Results and Discussion}

\subsection{Comparison of Agronomic Characteristics}

The compiled database includes 451 observations of agronomic traits from studies carried out in Sardinia, for a total of 19 sites for 17 different crops. The diversity of studies included was intended to facilitate regional assessment, as a result of multiple studies from a much wider range of locations and conditions. Among these characteristics, crop production and input requirements are the most important to assess the suitability of different crops. In particular, intraspecific biomass yield comparison provides the effectiveness of the crops and cultivars in terms of crop management practices, while productive capacity compared with first-generation bioenergy feedstock types (interspecific assessment) gains a detailed understanding useful to identify the most promising bioenergy crops [56]. An overview of the main agronomic traits, humidity and fermentation sugars was reported in the Tables S1 and S2 for annual and perennial crops, respectively. Figure 3 shows the box and whisker plot diagram for above-ground biomass yield for the crops evaluated. An average yield of $15 \mathrm{t} \cdot \mathrm{ha}^{-1}$ was taken into account as reasonable and realistic yield expected from the crops analysed [57].

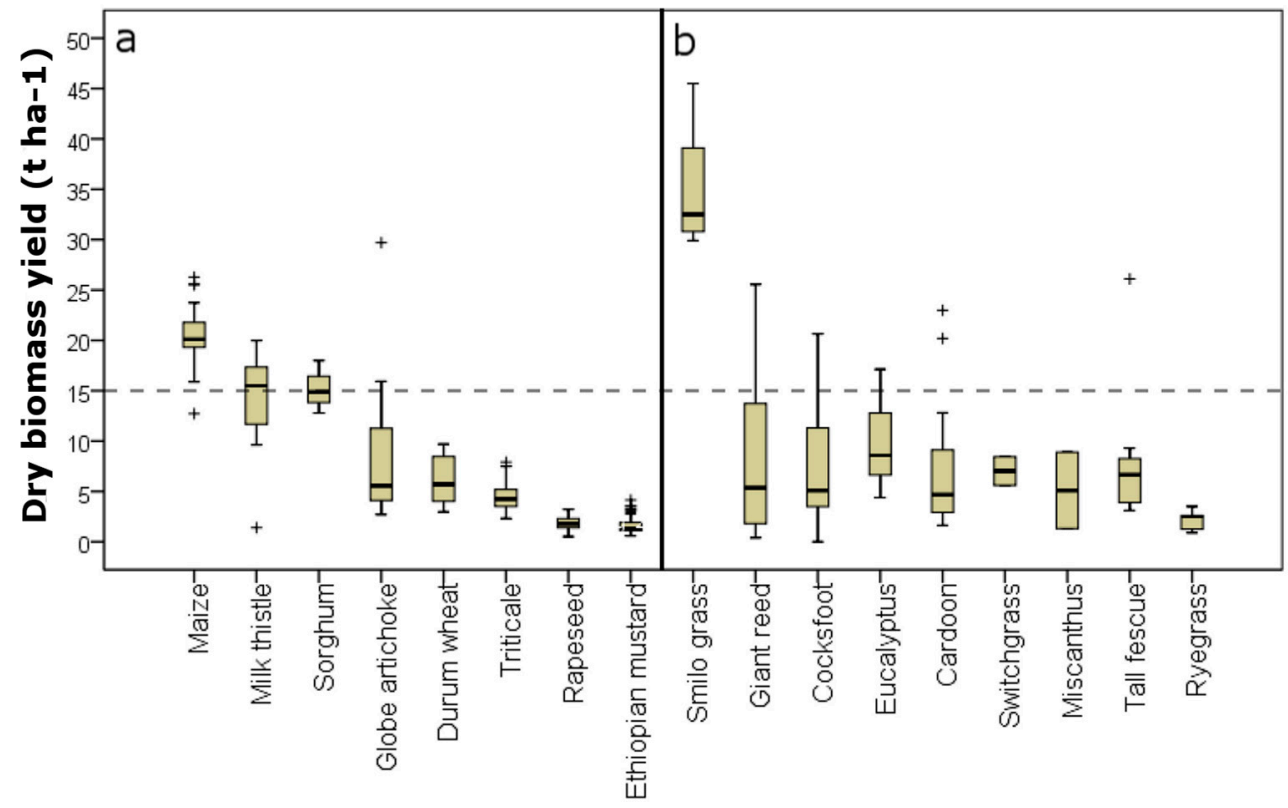

Figure 3. Box-plot of biomass yield for annual crops (a) and perennial crops (b) from 451 observations of 19 sites coming from studies carried out in Sardinia. The box represents the lower and upper quartile, solid horizontal line represents the median, tails represent the highest and lowest extremes, markers represent the outliers. Dashed line indicates a reference biomass production of $15 \mathrm{t} \cdot \mathrm{ha}^{-1}$.

The review of the available literature data for Sardinia showed that among the crops considered, the most promising candidates for bioenergy production in the study area giant reed and native germoplasm of perennial grasses among perennials (e.g., smilo grass, tall fescue and cocksfoots), and milk thistle among annuals.

These results seem to be consistent with other research indicating that perennial lignocellulosic species on marginal and semi-arid Mediterranean land have the potential to effectively support biomass energy value chains [28,58-60]. Perennial lignocellulosic crops are less flexible than the annual crops in terms of propagation, processing and utilization, but they can provide profitable alternatives to the food crops. Overall, ligno-cellulosic perennial crops are recognized for providing environmental 
services such as soil erosion control, carbon storage and suitable habitats for wildlife [42,61]. In addition, they can significantly contribute to increase soil quality and fertility, water cycle dynamics and microbial activities, with promising potential to remediate contamination of water, soils and sediments [62]. In a meta-analysis on yield data for 36 different crop species, Laurent et al. [31] found that second-generation crops such as giant reed and miscanthus were more productive than first-generation feedstocks and woody crops. However, all of these data must be interpreted with caution because a large amount of data found in literature comes from small plot experiments, which lead to overestimate crop yields when grown at large scale [57].

Results from annual field species provides some support for the conceptual premise that milk thistle (Cardueae crop) can be a suitable bioenergy crop thanks to the relatively stable production under minimal energy input (especially nitrogen application and reduced tillage) and high water use efficiency $[60,63,64]$. As recently observed by Ledda et al. [65] in Sardinia, milk thistle may be considered as a good source of biomass for energy purposes, and this is also reported in other studies investigating the chemical composition of Cardueae crop [66,67]. Nevertheless, for Cardueae crops further experimental investigations are needed to identify suitable genotypes and agronomic practices, as well as to address the decreasing production rate over time reported by various authors $[60,68]$.

In the overview of studies, reported biomass yields are quite variable, in relation to species and cultivar, fertilizer and irrigation application rates, soil type, crop management and, in some cases, dependent on the size of the field experiments (e.g., single plant plots vs. large plots). Generally, some annual crops show higher median yields values than perennial. The highest performance of annual crops depends on high energetic and agronomic inputs like fertilizers, pesticides, irrigation and tillage operations. Conversely, perennial crops combine low agronomic requirements with more homogeneous median (Figure 3). Detailed examination of energy comparison for crops in European agricultural systems by Venturi and Venturi [69] showed that row crops (e.g., wheat, maize, sugar beet) have a low energy balance ratio (range 1-4) when compared to lignocellulosic crops such as giant reed and cardoon (range 10-75). For these reasons row crops are considered unsuitable for this environment for bioenergy production. Certainly, one criticism of much of the literature on annual crops is that they may have a higher environmental impact, especially for soil compaction, erosion and run-off, that should be evaluated with an in-deep life cycle assessment.

Specifically, sorting out the yield response of annual crops, median yield was highest for maize ( $20 \mathrm{t} \cdot \mathrm{ha}^{-1}$ —dry matter), followed by milk thistle (>15 th ha ${ }^{-1}$ —dry matter) and sweet sorghum ( 15 $\mathrm{t} \cdot \mathrm{ha}^{-1}$ —dry matter). The high harvestable yield of the crop residues of the globe artichoke cultivar 'Mardigal' reached a maximum of $29.7 \mathrm{t} \cdot \mathrm{ha}^{-1}$ of dry matter, followed by cultivar 'Tema' (15.9 t.ha $\left.{ }^{-1}\right)$, 'C3' (11.2 t.ha $\left.{ }^{-1}\right)$, 'Spinoso sardo' (6.4 t. ha $\left.{ }^{-1}\right)$ and 'Violetto' (5.7 t.ha $\left.{ }^{-1}\right)$ [70]. Clearly, these observations come from experimental plots and therefore need to be interpreted with caution. Among annual species, it is interesting to note that milk thistle produced up to $20 \mathrm{t} \cdot \mathrm{ha}^{-1}$ of dry biomass under rainfed conditions and low nitrogen input $[65,71]$. Conversely, grain crops such as cereals and oilseeds showed more stable but lower harvestable yields $\left(\sim 7 \mathrm{t} \cdot \mathrm{ha}^{-1}\right.$ durum wheat; $\sim 6 \mathrm{t} \cdot \mathrm{ha}^{-1}$ triticale; $^{-}$ $\sim 2 \mathrm{t} \cdot \mathrm{ha}^{-1}$ rapeseed and Ethiopian mustard) (Figure 3 ). For grain crops the biomass yields do not take into account the harvestable straw.

With regard to nitrogen input, maize, sorghum and globe artichoke had the highest values $\left(300,150\right.$ and $150 \mathrm{~kg} \cdot \mathrm{ha}^{-1}$, respectively) always associated with irrigation rates (up to $570 \mathrm{~mm} \cdot \mathrm{ha}^{-1}$ ). These results provide further support for the hypothesis that, under semi-arid climates, biomass feedstock production is highly dependent on water availability [72]. Likewise, in Mediterranean cropping systems the highest yields of row crops are associated with high tillage intensity and have the potential to induce soil erosion, nitrogen leaching and decreasing soil organic carbon [73]. Unfortunately, studies of biomass crops have not dealt with byproduct yields of oilseed crops, and thus it is difficult to make a direct comparison with other bioenergy crops. Similarly, data on fermentation sugars such as cellulose and hemicellulose are very scarce and hence it is not possible to come to any reliable conclusion. 
Analyzing perennial crops, the median yield was highest for two smilo grass ecotype ( $\sim 45 \mathrm{t} \cdot \mathrm{ha}^{-1}$-dry matter; $\sim 40 \%$ cellulose content), while eight local accessions have reached a remarkable biomass yield (over $30 \mathrm{t} \cdot \mathrm{ha}^{-1}$ — dry matter) measured on a single plant basis [74]. Furthermore, in the same study, the tall fescue cultivar 'Flecha', identified as a benchmark, showed high yields $\left(\sim 26 \mathrm{t} \cdot \mathrm{ha}^{-1}\right)$ associated with drought tolerance without fertilizers and irrigation. However, these interesting results come from single plant plots and are likely to be related to a good rainfall distribution over the growing seasons. In these trials all of smilo grass cultivars were derived from seeds collected from native populations all over Sardinia [74]. In a previous observation on tall fescue cultivars carried out in Sardinia, Lelièvre et al. [75] highlighted good productivity $\left(\sim 9.3 \mathrm{t} \cdot \mathrm{ha}^{-1}\right.$ —cultivar 'Flecha') and resistance to summer drought stress as a consequence of high productivity and vigorous growth during the cool season. Similarly, cocksfoots cultivar 'Jana' selected in Sardinia from north-African and Sardinian germplasm showed a good productivity $\left(\sim 16 \mathrm{t} \cdot \mathrm{ha}^{-1}\right)$ in rainfed conditions with low-input fertilisation, and was among the best productive cultivars under irrigation (up to $\sim 20 \mathrm{t} \cdot \mathrm{ha}^{-1}$ ) [76]. On the contrary, native perennial ryegrass accessions show low yield potential and high variability of morphological and productive traits $\left(\sim 3.5 \mathrm{t} \cdot \mathrm{ha}^{-1}\right)$ [77]. Taken together, these results suggest that native germoplasm of perennial grasses could represent a valuable low-input rainfed alternative for bioenergy production in Mediterranean environment. Further research should be undertaken in breeding programs to better study their long-term agronomic potential. In addition to information from the literature, unpublished information from experimental fields for giant reed and switchgrass has been collected and included in this paper (see for more details Supplementary Materials Table S2). Field trial results for giant reed carried out in the Sulcis area showed interesting above-ground yields in the first year (up to $7.2 \mathrm{t} \cdot \mathrm{ha}^{-1}$-dry matter), with a remarkable increase of about $72 \%$ in the second year (25.6 tha ${ }^{-1} —$ dry matter) [78].

Similarly, Christou et al. [79] observed considerable yield peak at the second year in North Sardinia (24.6 tha $\mathrm{a}^{-1}$-dry matter) in a field-trial carried out without irrigation but in a plot with good soil conditions very near to a stream channel. Interestingly, several authors reported similar trend of biomass productivity in Mediterranean environment for giant reed. In studies carried out in South Italy, Copani et al. [80] found a rapid increase (+92\%) of biomass dry yield from establishment year to third year (from 2.6 to $31.3 \mathrm{t} \cdot \mathrm{ha}^{-1}$ ), while Cosentino et al. [81] observed an increase $(+50 \%)$ between first and second year (11-22 $\left.\mathrm{t} \cdot \mathrm{ha}^{-1}\right)$. Likewise, in the field trial in the Sulcis area, switchgrass showed good yields in the first year (5.6 tha ${ }^{-1}$ - dry matter) and an increase in the second year (8.44 $\mathrm{t} \cdot \mathrm{ha}^{-1}$-dry matter) [78]. However, with a small sample size, further work needs to be done to establish long-term productivity.

Little information is available for Miscanthus in Sardinia. One study by Christou et al. [79] reported harvestable yields reached in the second year ( $\sim 9 \mathrm{t} \cdot \mathrm{ha}^{-1} \_$dry matter) comparable with productions reported by Monti et al. [82] for a field trial carried out in Sicily. In contrast to earlier findings, the miscanthus yield reported by Angelini et al. [28] in the second year (48 tha ${ }^{-1}$-dry matter), in a long-term field experiment carried out in central Italy, indicated that higher yields than those of the study area ( $29 \mathrm{t} \cdot \mathrm{ha}^{-1}$ averaged from 2 to 12 years of growth) can be obtained under wetted conditions. A low median yield was shown by cardoon ( $6.7 \mathrm{t} \cdot \mathrm{ha}^{-1} —$ dry matter) [65], while an exception are the values reported by Christou et al. [79] (up to $23 \mathrm{t} \cdot \mathrm{ha}^{-1}$-dry matter) in line with some published studies in Italy indicating higher aboveground dry biomass yield for this crop [83-85]. Observed differences can be explained in part by the diverse agronomic techniques and genotypes (i.e., cultivated and wild cardoon) [86], although the pedo-climatic context was the same found for milk thistle. However, the available data on harvestable biomass need to be interpreted with caution due to the limited amount of yield data available for some species and not always expressed as dry matter. As regard to woody crops, Eucalyptus globulus showed good productivity ( $\sim 68 \mathrm{t} \cdot \mathrm{ha}^{-1}$ —dry matter) when managed as short-rotation forestry biomass and harvested at the end of a four-year cycle [87]. Conversely, eucalyptus clones showed lower productivity ( $34 \mathrm{t} \cdot \mathrm{ha}^{-1}$-dry matter for the best clone) in a field trial managed as short-rotation coppice harvested at the end of three year harvest cycle [88]. 
However, in the latter case significant insect pest attacks were observed that compromised biomass yields. In summary, eucalyptus species grown under Mediterranean rainfed conditions could provide remarkable biomass production when grown in soils with good hydrologic conditions. With regard to fertilizers and irrigation demand, perennial crops generally require low energy input and agronomic practices. Irrigation water requirement for giant reed during the growing period shows an average of $600 \mathrm{~mm}$ in the best performing field trial in south Sardinia with a level of $100 \mathrm{~kg}$ nitrogen $\mathrm{ha}^{-1}$ [78]. As stressed by Cosentino et al. [89] giant reed was able to uptake water at 160-180 cm soil depth when irrigation was applied. In addition, results of the field trial experiment carried out in Northern Italy showed that root biomass of giant reed can exhibits a proportional deep root system and constant water capture [90], tolerating drought periods, thanks to its ability to improve water use efficiency and to maintain a high level of biomass production. Miscanthus and giant reed are recognized for efficiently recycle nitrogen from the above-ground biomass to the rhizomes [91], and generally biomass production is not significantly affected by nitrogen fertilization [89,92]. Giant reed proved to be a very plastic crop [93], able to achieve impressive production under high-input, but at the same time able to provide profitable productions in marginal land. Further research should be undertaken in the future to investigate the most suitable bioenergy crops and agronomic practices for maximizing the growth and yield in various kinds of polluted lands [94].

\subsection{Land Use/Cover Scenario}

According to our GIS-based multi-criteria approach, the total area suitable for biomass cultivation, considering a supply radius of $70 \mathrm{~km}$ from a hypothetical biorefinery located in Portoscuso was 51,000 ha (i.e., $53 \%$ of the total agricultural area). The estimated area is comparable with that reported by RAS [95] (i.e., 37,000 ha potentially available for bioenergy crops). This large extension of arable land may be partly explained by the availability of cropland due to the decline of the cereal cropping system, especially durum wheat, in the last two decades [96]. Other drivers are the subsidies provided from the Common Agriculture Policy for the livestock sector (i.e., sheep and goats) and the volatility splillovers across international energy and cereal commodity markets during and after the financial crisis [97]. The identified suitable areas almost overlap entirely the agricultural flat zones within the ILRC 'Cixerri' (Figure 4). Details on the available areas are given in Table 3.

Table 3. Available land, soil class units, land use/cover and suitable land areas for biomass production across the ILRC 'Cixerri'.

\begin{tabular}{cc}
\hline Available Areas & ILRC 'Cixerri' (ha) \\
\hline Total area & 9180 \\
Equipped area with irrigation infrastructures & 6580 \\
Arable land & 6104 \\
Arable land-soil class I-II & 1186 \\
Arable land-soil class III-V & 4813 \\
Rainfed arable land 2015 & 5679 \\
Irrigated arable land 2015 & 425 \\
Vineyards, orchards 2015 & 477 \\
Woods, natural areas 2015 & 803 \\
Land suitability area ${ }^{1}$ & 2883
\end{tabular}

Note: ${ }^{1}$ Data obtained by subtracting land use/cover layer constraints from land suitability map.

Considering a land-sparing scenario, all available rainfed arable land can be converted from traditional uses for biomass feedstock production. Land-sharing design mitigates negative impacts of bioenergy crops by promoting large patches of buffer riparian corridors and natural habitats interspersed with areas of traditional crops. The results indicate that the available surface area for biomass cultivation is 5679 ha, accounting for $86 \%$ of the total available area equipped with irrigation infrastructures. On the other and, considering a land-sharing scenario, only suitable arable land as 
a result of our GIS-based model can be used for biomass production. In this case, the cultivable area is 2883 ha, accounting for $44 \%$ of the area equipped with irrigation infrastructures. According to these results and considering an average production of $15 \mathrm{t} \cdot \mathrm{ha}^{-1}$, approximately $85,000 \mathrm{t} \cdot \mathrm{ha}^{-1} \mathrm{of}^{\mathrm{s}}$ biomass can be produced considering a land-sparing scenario compared with 43,000 t.ha ${ }^{-1}$ from the land-sharing scenario.

With regard to the most contaminated area (Figure 4), the available surface for biomass cultivation resulting from our suitability model is approximately 1000 ha. Taking into account that the area is outside the areas equipped with irrigation infrastructures, the most suitable crops should be rainfed species.
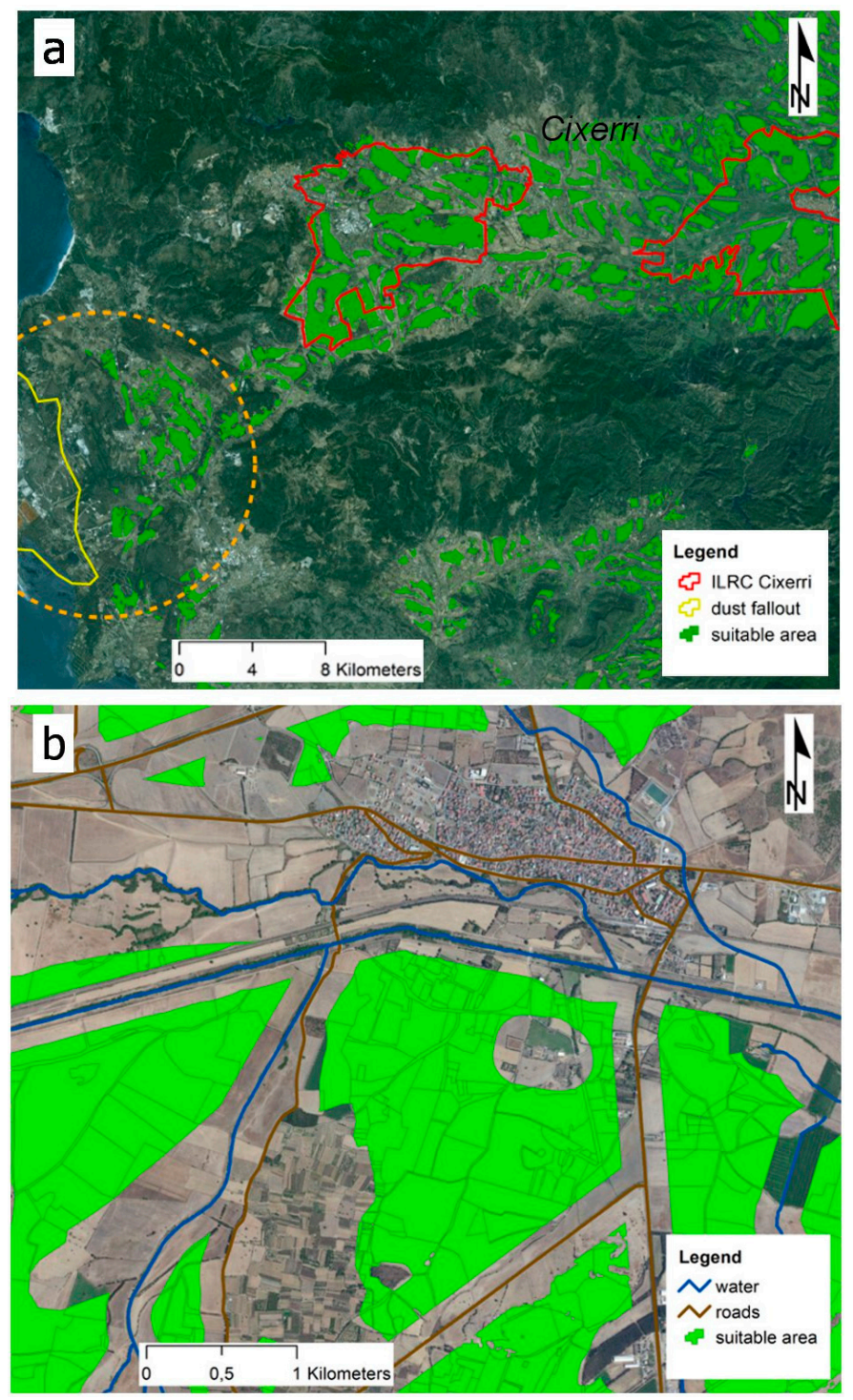

Figure 4. (a) Suitable marginal lands for Land Reclamation and Irrigation consortium 'Cixerri'. Dashed circle indicates the most contaminated area; (b) Zoom-in on suitable areas nearby buffer zones around built-up areas, rivers and roads.

Despite our multi-criteria procedure for land suitability modeling is based on accurate and detailed data and integrate agro-ecological knowledge at a detailed geographical scale, caution is required due to certain limitations. First, one source of weakness may originate from the scale of the soil map used. In fact, both the low spatial and thematic resolution and the inclusion of mixed classes in larger units may lead to an overestimation of suitable areas. Second, it was not possible to 
assess detailed information on soil properties such as $\mathrm{pH}$, soil depth and plant nutrient availability. Since $\mathrm{pH}$ levels and soil fertility strongly influence plant growth, geospatial maps on nutrient content would likely improve model performances and spatial pattern of the final map. Finally, detailed land use/cover data for the whole study area are not available, thus further research should be carried out to establish the amount of suitable land at fine spatial resolution. For all of these reasons, we did not further differentiate the suitability map into subclasses as a result of quantitative scoring based on input dataset.

\section{Conclusions}

This study set out to determine the agronomic feasibility for the cultivation of dedicated energy crops on a marginal and contaminated territory located in the Sulcis area, Italy. This might be the first step towards comprehensive approaches to support effective value chains, meeting industry's feedstock demand and minimizing impacts over marginal land.

Our findings suggest that the most promising candidate crops for a large deployment of bioenergy cultivation are giant reed and native perennial grasses, among perennials, and milk thistle among annuals. Giant reed and perennial grasses show good comparative performances in terms of yield, irrigation needs, water use efficiency and fertilizer use. Milk thistle, among annuals, is one of the most promising crops in Sardinia for the good levels of yield, even under non-irrigated conditions, and for an interesting content of fermentable sugars. Results indicated that about 51,000 ha could be available for biomass cultivation in an area located within a supply radius of $70 \mathrm{~km}$ from a hypothetical biorefinery and considering a land-sparing scenario, where all available rainfed arable land is converted to biomass production. A pilot investigation within the Land Reclamation and Irrigation Consortium 'Cixerri', carried out considering the actual land use/cover, revealed that about 5700 ha can be potentially exploited for biomass cultivation, accounting for $86 \%$ of the total available area equipped with irrigation infrastructures. Lastly, focusing on the most contaminated area, the available surface is approximately $1000 \mathrm{ha}$, falling within an unequipped area for irrigation, thus most suitable for rainfed crops such as those identified in this study.

Supplementary Materials: The following are available online at www.mdpi.com/1996-1073/9/11/895/s1, Table S1: Overview of agronomic characteristics of annual biomass crops inventoried in Sardinia, Table S2: Overview of agronomic characteristics of perennial biomass crops inventoried in Sardinia.

Acknowledgments: This project has received funding from the European Union's Horizon 2020 research and innovation programme under grant agreement No. 691846. The authors thank Michele Fiori and Agenzia Regionale per la Protezione dell'Ambiente della Sardegna-Dip. Meteoclimatico (ARPAS) for having provided agrometeorological data that have been used in this study. Thanks also to the Ing. Alfredo Piccolo from Consorzio Cooperative Sardegna e Natura s.c.a. for having provided data on agronomic field trials conducted in Sardinia. We are also grateful to Fabiola Fagnani for English improvement. The experiments that produced the unpublished data on giant reed [78] are the outcome of a cooperation between Biochemtex Agro S.p.A. and the University of Sassari: for these data, authors acknowledge the contribution of Federico Maria Grati, project manager and Grissanta Diana, agronomist, Biochemtex Agro S.p.A., and the technical support of Tore Pala, Agostino Piredda, and Giacomo Patteri, University of Sassari.

Author Contributions: Giuseppe Pulighe conceived and designed the structure of the paper. Pasquale Nino carried out the land use/cover map. Guido Bonati, Stefano Fabiani, Tommaso Barsali, Silvia Vanino, Flavio Lupia, Pasquale Nino, Pasquale Arca and Pier Paolo Roggero provided general supervision for research design, methodology and analysis. All authors contributed equally on writing the paper. All authors read and agreed to the final article.

Conflicts of Interest: The authors declare no conflict of interest.

\section{References}

1. Gabrielle, B.; Bamière, L.; Caldes, N.; de Cara, S.; Decocq, G.; Ferchaud, F.; Loyce, C.; Pelzer, E.; Perez, Y.; Wohlfahrt, J.; et al. Paving the way for sustainable bioenergy in Europe: Technological options and research avenues for large-scale biomass feedstock supply. Renew. Sustain. Energy Rev. 2014, 33, 11-25. [CrossRef]

2. Farrell, A.E.; Plevin, R.J.; Turner, B.T.; Jones, A.D.; O'Hare, M.; Kammen, D.M. Ethanol can contribute to energy and environmental goals. Science 2006, 311, 506-508. [CrossRef] [PubMed] 
3. Innovating for Sustainable Growth: A Bioeconomy for Europe; COM(2012) 60 Final; European Commission: Brussels, Belgium, 2012.

4. Directive of the European Parliament and of the Council Amending Directive 98/70/ec Relating to the Quality of Petrol and Diesel Fuels and Amending Directive 2009/28/ec on the Promotion of the Use of Energy from Renewable Sourc; European Commission: Brussels, Belgium, 2012.

5. DECRETO LEGISLATIVO 3 Marzo 2011, n. 28. Attuazione Della Direttiva 2009/28/CE Sulla Promozione Dell'uso Dell'energia da Fonti Rinnovabili, Recante Modifica e Successiva Abrogazione Delle Direttive 2001/77/CE e 2003/30/CE. Available online: http://www.bosettiegatti.eu/info/norme/statali/2011_0028. htm (accessed on 10 July 2006). (In Italian)

6. Golden, J.S.; Handfield, R.B.; Daystar, J.; McConnell, T.E. An Economic Impact Analysis of the U. S. Biobased Products Industry; A Report to the Congress of the United States of America; United States Department of Agriculture: Washington, DC, USA, 2015.

7. Piotrowski, S.; Carus, M.; Carrez, D. European Bioeconomy in Figures; Nova-Institute for Ecology and Innovation: Hürth, Germany, 2016.

8. Ghezehei, S.B.; Shifflett, S.D.; Hazel, D.W.; Nichols, E.G. SRWC bioenergy productivity and economic feasibility on marginal lands. J. Environ. Manag. 2015, 160, 57-66. [CrossRef] [PubMed]

9. Stoof, C.R.; Richards, B.K.; Woodbury, P.B.; Fabio, E.S.; Brumbach, A.R.; Cherney, J.; Das, S.; Geohring, L.; Hansen, J.; Hornesky, J.; et al. Untapped Potential: Opportunities and Challenges for Sustainable Bioenergy Production from Marginal Lands in the Northeast USA. BioEnergy Res. 2015, 8, 482-501. [CrossRef]

10. Shortall, O.K. "Marginal land" for energy crops: Exploring definitions and embedded assumptions. Energy Policy 2013, 62, 19-27. [CrossRef]

11. Gopalakrishnan, G.; Cristina Negri, M.; Snyder, S.W. A Novel Framework to Classify Marginal Land for Sustainable Biomass Feedstock Production. J. Environ. Qual. 2011, 40, 1593. [CrossRef] [PubMed]

12. Solinas, S.; Fazio, S.; Seddaiu, G.; Roggero, P.P.; Deligios, P.A.; Doro, L.; Ledda, L. Environmental consequences of the conversion from traditional to energy cropping systems in a Mediterranean area. Eur. J. Agron. 2015, 70, 124-135. [CrossRef]

13. Dale, V.H.; Kline, K.L.; Buford, M.A.; Volk, T.A.; Tattersall Smith, C.; Stupak, I. Incorporating bioenergy into sustainable landscape designs. Renew. Sustain. Energy Rev. 2016, 56, 1158-1171. [CrossRef]

14. Valentine, J.; Clifton-Brown, J.; Hastings, A.; Robson, P.; Allison, G.; Smith, P. Food vs. fuel: The use of land for lignocellulosic "next generation" energy crops that minimize competition with primary food production. GCB Bioenergy 2012, 4, 1-19. [CrossRef]

15. Jansen, R.A. Second Generation Biofuels and Biomass: Essential Guide for Investors, Scientists and Decision Makers, 1st ed.; WILEY-VCH Verlag GmbH \& Co. KGaA: Weinheim, Germany, 2013.

16. Bartle, J.R.; Abadi, A. Toward sustainable production of second generation bioenergy feedstocks. Energy Fuels 2010, 24, 2-9. [CrossRef]

17. Barbosa, B.; Boléo, S.; Sidella, S.; Costa, J.; Duarte, M.P.; Mendes, B.; Cosentino, S.L.; Fernando, A.L. Phytoremediation of Heavy Metal-Contaminated Soils Using the Perennial Energy Crops Miscanthus spp. and Arundo donax L. BioEnergy Res. 2015, 8, 1500-1511. [CrossRef]

18. Antonkiewicz, J.; Koloodziej, B.; Bielinska, E.J. The use of reed canary grass and giant miscanthus in the phytoremediation of municipal sewage sludge. Environ. Sci. Pollut. Res. 2016, 23, 9505-9517. [CrossRef] [PubMed]

19. Pavel, P.-B.; Puschenreiter, M.; Wenzel, W.W.; Diacu, E.; Barbu, C.H. Aided phytostabilization using Miscanthus sinensis $\times$ giganteus on heavy metal-contaminated soils. Sci. Total Environ. 2014, 479-480, 125-131. [CrossRef] [PubMed]

20. World Atlas of Desertification, 2nd ed.; United Nations Environment Programme (UNEP): Nairobi, Kenya, 1997.

21. Aru, A.; Baladaccini, P.; Delogu, G.; Dessena, M.A.; Madrau, S.; Melis, R.T.; Vacca, A. Nota Illustrativa Alla Carta Dei Suoli Della Sardegna, Scala 1:250.000; Dipartimento di Scienze della Terra Università di Cagliari: Cagliari, Italy, 1991. (In Italian)

22. Cherchi, A.; Da Pelo, S.; Ibba, A.; Mana, D.; Buosi, C.; Floris, N. Benthic foraminifera response and geochemical characterization of the coastal environment surrounding the polluted industrial area of Portovesme (South-Western Sardinia, Italy). Mar. Pollut. Bull. 2009, 59, 281-296. [CrossRef] [PubMed] 
23. Schintu, M.; Buosi, C.; Galgani, F.; Marrucci, A.; Marras, B.; Ibba, A.; Cherchi, A. Interpretation of coastal sediment quality based on trace metal and PAH analysis, benthic foraminifera, and toxicity tests (Sardinia, Western Mediterranean). Mar. Pollut. Bull. 2015, 94, 72-83. [CrossRef] [PubMed]

24. ARPA SARDEGNA-Piano di Disinquinamento per il Risanamento del Territorio del Sulcis Iglesiente. Available online: $\mathrm{http}: / / \mathrm{www}$. sardegnaambiente.it/index.php?xsl=612\&s=149955\&v=2\&c=4586\&idsito=21 (accessed on 10 May 2016). (In Italian)

25. Comune di Portoscuso Ordinanza N.9 del 6 marzo 2014-Divieto di commercializzazione o distribuzione a qualunque titolo di alimenti derivanti dalle produzioni nel Comune di Portoscuso. Available online: https: / gruppodinterventogiuridicoweb.files.wordpress.com/2014/03/ordinanza-n-9-del-6-marzo2014-divieto-di-commercializzazione-di-alimenti.pdf (accessed on 13 May 2016). (In Italian)

26. Varrica, D.; Tamburo, E.; Milia, N.; Vallascas, E.; Cortimiglia, V.; de Giudici, G.; Dongarrà, G.; Sanna, E.; Monna, F.; Losno, R. Metals and metalloids in hair samples of children living near the abandoned mine sites of Sulcis-Inglesiente (Sardinia, Italy). Environ. Res. 2014, 134, 366-374. [CrossRef] [PubMed]

27. Boehmel, C.; Lewandowski, I.; Claupein, W. Comparing annual and perennial energy cropping systems with different management intensities. Agric. Syst. 2008, 96, 224-236. [CrossRef]

28. Angelini, L.G.; Ceccarini, L.; Nassi o Di Nasso, N.; Bonari, E. Comparison of Arundo donax L. and Miscanthus $x$ giganteus in a long-term field experiment in Central Italy: Analysis of productive characteristics and energy balance. Biomass Bioenergy 2009, 33, 635-643. [CrossRef]

29. Cosentino, S.L.; Copani, V.; Patanè, C.; Mantineo, M.; D’Agosta, G.M. Agronomic, Energetic and Environmental Aspects of Biomass Energy Crops Suitable for Italian Environments. Ital. J. Agron. 2008, 3, 81. [CrossRef]

30. Zegada-Lizarazu, W.; Elbersen, H.W.; Cosentino, S.L.; Zatta, A.; Alexopoulou, E.; Monti, A. Agronomic aspects of future energy crops in Europe. Biofuels Bioprod. Biorefin. 2010, 4, 674-691. [CrossRef]

31. Laurent, A.; Pelzer, E.; Loyce, C.; Makowski, D. Ranking yields of energy crops: A meta-analysis using direct and indirect comparisons. Renew. Sustain. Energy Rev. 2015, 46, 41-50. [CrossRef]

32. Beccali, M.; Columba, P.; D'Alberti, V.; Franzitta, V. Assessment of bioenergy potential in Sicily: A GIS-based support methodology. Biomass Bioenergy 2009, 33, 79-87. [CrossRef]

33. Lovett, A.; Sünnenberg, G.; Dockerty, T. The availability of land for perennial energy crops in Great Britain. GCB Bioenergy 2014, 6, 99-107. [CrossRef]

34. Fiorese, G.; Guariso, G. A GIS-based approach to evaluate biomass potential from energy crops at regional scale. Environ. Model. Softw. 2010, 25, 702-711. [CrossRef]

35. Lewis, S.; Kelly, M. Mapping the Potential for Biofuel Production on Marginal Lands: Differences in Definitions, Data and Models across Scales. ISPRS Int. J. Geo-Inf. 2014, 3, 430-459. [CrossRef]

36. European Environment Agency-EEA. Available online: http://land.copernicus.eu/pan-european/corineland-cover (accessed on 2 April 2016).

37. Regione Autonoma Della Sardegna-Sardegna Geoportale. Available online: http://www. sardegnageoportale.it/index.php?xsl=1594\&s=40\&v=9\&c=8753\&n=10 (accessed on 2 April 2016).

38. Worldclim-Global Climate Data. Available online: http://www.worldclim.org/ (accessed on 2 April 2016).

39. Istituto Nazionale di Economia Agraria (INEA). Atlante dell'Irrigazione Regioni Meridionali; Rapporti Irrigazione; INEA: Rome, Italy, 2001. (In Italian)

40. Seabrook, L.; McAlpine, C.; Fensham, R. Cattle, crops and clearing: Regional drivers of landscape change in the Brigalow Belt, Queensland, Australia, 1840-2004. Landsc. Urban Plan. 2006, 78, 373-385. [CrossRef]

41. Don, A.; Osborne, B.; Hastings, A.; Skiba, U.; Carter, M.S.; Drewer, J.; Flessa, H.; Freibauer, A.; Hyvönen, N.; Jones, M.B.; et al. Land-use change to bioenergy production in Europe: Implications for the greenhouse gas balance and soil carbon. GCB Bioenergy 2012, 4, 372-391. [CrossRef]

42. Immerzeel, D.J.; Verweij, P.A.; van der Hilst, F.; Faaij, A.P.C. Biodiversity impacts of bioenergy crop production: A state-of-the-art review. GCB Bioenergy 2014, 6, 183-209. [CrossRef]

43. Plieninger, T.; Gaertner, M. Harnessing degraded lands for biodiversity conservation. J. Nat. Conserv. 2011, 19, 18-23. [CrossRef]

44. Miyake, S.; Smith, C.; Peterson, A.; McAlpine, C.; Renouf, M.; Waters, D. Environmental implications of using "underutilised agricultural land" for future bioenergy crop production. Agric. Syst. 2015, 139, 180-195. [CrossRef] 
45. Lovett, A.A.; Sünnenberg, G.M.; Richter, G.M.; Dailey, A.G.; Riche, A.B.; Karp, A. Land use implications of increased biomass production identified by gis-based suitability and yield mapping for miscanthus in england. Bioenergy Res. 2009, 2, 17-28. [CrossRef]

46. Andersen, R.S.; Towers, W.; Smith, P. Assessing the potential for biomass energy to contribute to Scotland's renewable energy needs. Biomass Bioenergy 2005, 29, 73-82. [CrossRef]

47. Abolina, E.; Volk, T.A.; Lazdina, D. GIS based agricultural land availability assessment for the establishment of short rotation woody crops in Latvia. Biomass Bioenergy 2015, 72, 263-272. [CrossRef]

48. CREA-Consiglio per la ricerca in agricoltura e l'analisi dell'economia agraria. Available online: http: //www.crea.gov.it/politiche-e-bioeconomia/ (accessed on 2 April 2016).

49. Delivand, M.K.; Cammerino, A.R.B.; Garofalo, P.; Monteleone, M. Optimal locations of bioenergy facilities, biomass spatial availability, logistics costs and GHG (greenhouse gas) emissions: A case study on electricity productions in South Italy. J. Clean. Prod. 2015, 99, 129-139. [CrossRef]

50. Garofalo, P.; D'Andrea, L.; Vonella, A.V.; Rinaldi, M.; Palumbo, A.D. Energy performance and efficiency of two sugar crops for the biofuel supply chain. Perspectives for sustainable field management in southern Italy. Energy 2015, 93, 1548-1557. [CrossRef]

51. European Parliament, Council of the European Union. Directive 2009/28/EC on the Promotion of the Use of Energy from Renewable Sources and Amending and Subsequently Repealing Directives 2001/77/EC and 2003/30/EC. Off. J. Eur. Union 2009, L 140, 16-47.

52. Tenerelli, P.; Carver, S. Multi-criteria, multi-objective and uncertainty analysis for agro-energy spatial modelling. Appl. Geogr. 2012, 32, 724-736. [CrossRef]

53. D’Urso, G. Nuove tecnologie per la stima dei fabbisogni irrigui a scala di bacino e comprensorio irriguo. In L'acqua in Agricoltura. Gestione Sostenibile Della Pratica Irrigua; Mastrolilli, M., Ed.; Edagricole-New Business Media: Milano, Italy, 2015; p. 421. (In Italian)

54. Anderson-Teixeira, K.J.; Duval, B.D.; Long, S.P.; DeLucia, E.H. Biofuels on the landscape: Is "land sharing" preferable to "land sparing"? Ecol. Appl. 2012, 22, 2035-2048. [CrossRef] [PubMed]

55. Fischer, J.; Brosi, B.; Daily, G.C.; Ehrlich, P.R.; Goldman, R.; Goldstein, J.; Lindenmayer, D.B.; Manning, A.D.; Mooney, H.A.; Pejchar, L.; et al. Should agricultural policies encourage land sparing or wildlife-friendly farming? Front. Ecol. Environ. 2008, 6, 380-385. [CrossRef]

56. Giannini, V.; Silvestri, N.; Dragoni, F.; Pistocchi, C.; Sabbatini, T.; Bonari, E. Growth and nutrient uptake of perennial crops in a paludicultural approach in a drained Mediterranean peatland. Ecol. Eng. 2015. [CrossRef]

57. Searle, S.Y.; Malins, C.J. Will energy crop yields meet expectations? Biomass Bioenergy 2014, 65, 3-12. [CrossRef]

58. Fernando, A.L.; Boléo, S.; Barbosa, B.; Costa, J.; Duarte, M.P.; Monti, A. Perennial Grass Production Opportunities on Marginal Mediterranean Land. Bioenergy Res. 2015, 8, 1523-1537. [CrossRef]

59. Dragoni, F.; Ragaglini, G.; Corneli, E.; o di Nasso, N.N.; Tozzini, C.; Cattani, S.; Bonari, E. Giant reed (Arundo donax L.) for biogas production: Land use saving and nitrogen utilisation efficiency compared with arable crops. Ital. J. Agron. 2015, 10, 192-201. [CrossRef]

60. Mantineo, M.; D'Agosta, G.M.; Copani, V.; Patanè, C.; Cosentino, S.L. Biomass yield and energy balance of three perennial crops for energy use in the semi-arid Mediterranean environment. Field Crop. Res. 2009, 114, 204-213. [CrossRef]

61. Chimento, C.; Almagro, M.; Amaducci, S. Carbon sequestration potential in perennial bioenergy crops: The importance of organic matter inputs and its physical protection. GCB Bioenergy 2014, 8, 111-121. [CrossRef]

62. Nsanganwimana, F.; Marchand, L.; Douay, F.; Mench, M. Arundo donax L., a Candidate for Phytomanaging Water and Soils Contaminated by Trace Elements and Producing Plant-Based Feedstock. A Review. Int. J. Phytoremediat. 2014, 16, 982-1017. [CrossRef] [PubMed]

63. Rana, G.; Ferrara, R.M.; Vitale, D.; D'Andrea, L.; Palumbo, A.D. Carbon assimilation and water use efficiency of a perennial bioenergy crop (Cynara cardunculus L.) in Mediterranean environment. Agric. For. Meteorol. 2016, 217, 137-150. [CrossRef]

64. Angelini, L.G.; Ceccarini, L.; Nassi o Di Nasso, N.; Bonari, E. Long-term evaluation of biomass production and quality of two cardoon (Cynara cardunculus L.) cultivars for energy use. Biomass Bioenergy 2009, 33, 810-816. [CrossRef] 
65. Ledda, L.; Deligios, P.A.; Farci, R.; Sulas, L. Biomass supply for energetic purposes from some Cardueae species grown in Mediterranean farming systems. Ind. Crop. Prod. 2013, 47, 218-226. [CrossRef]

66. Ciancolini, A.; Alignan, M.; Pagnotta, M.A.; Vilarem, G.; Crinò, P. Selection of Italian cardoon genotypes as industrial crop for biomass and polyphenol production. Ind. Crop. Prod. 2013, 51, 145-151. [CrossRef]

67. Francaviglia, R.; Bruno, A.; Falcucci, M.; Farina, R.; Renzi, G.; Russo, D.E.; Sepe, L.; Neri, U. Yields and quality of Cynara cardunculus L. wild and cultivated cardoon genotypes. A case study from a marginal land in Central Italy. Eur. J. Agron. 2016, 72, 10-19. [CrossRef]

68. Gherbin, P.; Monteleone, M.; Tarantino, E. Five year evaluation on cardoon (Cynara cardunculus L. var. altilis) biomass production in a Mediterranean environment. Ital. J. Agron. 2001, 5, 11-19.

69. Venturi, P.; Venturi, G. Analysis of energy comparison for crops in European agricultural systems. Biomass Bioenergy 2003, 25, 235-255. [CrossRef]

70. De Menna, F.; Malagnino, R.; Vittuari, M.; Molari, G.; Seddaiu, G.; Deligios, P.; Solinas, S.; Ledda, L. Potential Biogas Production from Artichoke Byproducts in Sardinia, Italy. Energies 2016, 9, 92. [CrossRef]

71. Sulas, L.; Ventura, A.; Murgia, L. Phytomass production from Silybum marianum for bioenergy. Opt. Méditerr. 2008, 487-490.

72. Stone, K.C.; Hunt, P.G.; Cantrell, K.B.; Ro, K.S. The potential impacts of biomass feedstock production on water resource availability. Bioresour. Technol. 2010, 101, 2014-2025. [CrossRef] [PubMed]

73. Migliorini, P.; Moschini, V.; Tittarelli, F.; Ciaccia, C.; Benedettelli, S.; Vazzana, C.; Canali, S. Agronomic performance, carbon storage and nitrogen utilisation of long-term organic and conventional stockless arable systems in Mediterranean area. Eur. J. Agron. 2014, 52, 138-145. [CrossRef]

74. Sulas, L.; Franca, A.; Sanna, F.; Re, G.A.; Melis, R.; Porqueddu, C. Biomass characteristics in Mediterranean populations of Piptatherum miliaceum-A native perennial grass species for bioenergy. Ind. Crop. Prod. 2015, 75, 76-84. [CrossRef]

75. Lelièvre, F.; Seddaiu, G.; Ledda, L.; Porqueddu, C.; Volaire, F. Water use efficiency and drought survival in Mediterranean perennial forage grasses. Field Crop. Res. 2011, 121, 333-342. [CrossRef]

76. Piano, E.; Pecetti, L.; Annicchiarico, P.; Carroni, A.M.; Fornasier, F.; Romani, M. Combining drought tolerance and responsiveness to summer moisture availability in cocksfoot (Dactylis glomerata L.) germplasm grown in Mediterranean environments. Aust. J. Agric. Res. 2004, 55, 1197-1204. [CrossRef]

77. Sanna, F.; Franca, A.; Porqueddu, C.; Piluzza, G.; Re, G.A.; Sulas, L.; Bullitta, S. Characterization of native perennial ryegrasses for persistence in mediterranean rainfed conditions. Span. J. Agric. Res. 2014, $12,1110$. [CrossRef]

78. Arca, P. Biomass Production Systems Based on Giant Reed (Arundo donax L.) under Mediterranean Conditions: Implantation Techniques and Soil Carbon Balance. Ph.D. Thesis, University of Sassari, Sassari, Italy, 2017; in preparation.

79. Christou, M.; Alexopoulou, E.; Cosentino, L.; Scordia, D.; Monti, A.; Zanetti, F.; Porqueddu, C.; Sulas, L. Productivity of perennial crops on marginal Mediterranean lands. In Proceedings of the Perennial Biomass Crops for a Resource-Constrained World, Stuttgard, Germany, 7-10 September 2015.

80. Copani, V.; Cosentino, S.L.; Testa, G.; Scordia, D. Agamic propagation of giant reed (Arundo donax L.) in semi-arid Mediterranean environment. Ital. J. Agron. 2013, 8, 18-24.

81. Cosentino, S.L.; Copani, V.; D'Agosta, G.M.; Sanzone, E.; Mantineo, M. First results on evaluation of Arundo donax L. clones collected in Southern Italy. Ind. Crop. Prod. 2006, 23, 212-222. [CrossRef]

82. Monti, A.; Zanetti, F.; Scordia, D.; Testa, G.; Cosentino, S.L. What to harvest when? Autumn, winter, annual and biennial harvesting of giant reed, miscanthus and switchgrass in northern and southern Mediterranean area. Ind. Crop. Prod. 2015, 75, 129-134. [CrossRef]

83. Ierna, A.; Mauro, R.P.; Mauromicale, G. Biomass, grain and energy yield in Cynara cardunculus L. as affected by fertilization, genotype and harvest time. Biomass Bioenergy 2012, 36, 404-410. [CrossRef]

84. Foti, S.; Mauromicale, G.; Raccuia, S.A.; Fallico, B.; Fanella, F.; Maccarone, E. Possible alternative utilization of Cynara spp. Ind. Crop. Prod. 1999, 10, 219-228. [CrossRef]

85. Raccuia, S.A.; Melilli, M.G. Biomass and grain oil yields in Cynara cardunculus L. genotypes grown in a Mediterranean environment. Field Crop. Res. 2007, 101, 187-197. [CrossRef]

86. Mauromicale, G.; Sortino, O.; Pesce, G.R.; Agnello, M.; Mauro, R.P. Suitability of cultivated and wild cardoon as a sustainable bioenergy crop for low input cultivation in low quality Mediterranean soils. Ind. Crop. Prod. 2014, 57, 82-89. [CrossRef] 
87. Bombelli, V.; Piccolo, A.; Marceddu, E. Prove agronomiche su colture energetiche area Sardegna-relazione tecnica finale, contratto ENEL-RAAWS 020/0/00. In Colture Erbacee da Biomassa per la Produzione di Energia Elettrica; Schenone, G., Ed.; ENEL s.p.a.: Milano, Italy, 1998; p. 51. (In Italian)

88. Facciotto, G. Ri.Selv.Italia-Sottoprogetto Scheda 2.3. Produttività Delle Specie: Prove di Colture a Turno Breve con Robinia ed Eucalitto (Biomasse Legnose ad Uso Energetico ed Industriale). Relazione Finale; CRA Unità di Ricerca per le Produzioni Legnose Fuori Foresta: Rome, Italy, 2007. (In Italian)

89. Cosentino, S.L.; Scordia, D.; Sanzone, E.; Testa, G.; Copani, V. Response of giant reed (Arundo donax L.) to nitrogen fertilization and soil water availability in semi-arid Mediterranean environment. Eur. J. Agron. 2014, 60, 22-32. [CrossRef]

90. Monti, A.; Zatta, A. Root distribution and soil moisture retrieval in perennial and annual energy crops in Northern Italy. Agric. Ecosyst. Environ. 2009, 132, 252-259. [CrossRef]

91. Lewandowski, I.; Schmidt, U. Nitrogen, energy and land use efficiencies of miscanthus, reed canary grass and triticale as determined by the boundary line approach. Agric. Ecosyst. Environ. 2006, 112, 335-346. [CrossRef]

92. Amaducci, S.; Facciotto, G.; Bergante, S.; Perego, A.; Serra, P.; Ferrarini, A.; Chimento, C. Biomass production and energy balance of herbaceous and woody crops on marginal soils in the Po valley. GCB Bioenergy 2016, 1-15. [CrossRef]

93. Borin, M.; Barbera, A.C.; Milani, M.; Molari, G.; Zimbone, S.M.; Toscano, A. Biomass production and N balance of giant reed (Arundo donax L.) under high water and $\mathrm{N}$ input in Mediterranean environments. Eur. J. Agron. 2013, 51, 117-119. [CrossRef]

94. Tripathi, V.; Edrisi, S.A.; Abhilash, P.C. Towards the coupling of phytoremediation with bioenergy production. Renew. Sustain. Energy Rev. 2016, 57, 1386-1389. [CrossRef]

95. Scano, E.A. Studio Sulle Potenzialità Energetiche Delle Biomasse; Regione Autonoma della Sardegna: Cagliari, Italy, 2013. (In Italian)

96. Roggero, P.P.; Bagella, S.; Deligios, P.; Ledda, L.; Gutierrez, M. Gestione dell'abbandono dei seminativi italiani in aree svantaggiate. In I GEORGOFILI, Situazione dei Seminativi nel Quadro Dell'agricoltura Italiana; Edizioni Polistampa: Firenze, Italy, 2010; pp. 147-171. (In Italian)

97. Saucedo, A.; Brümmer, B.; Jaghdani, T.J. The dynamic pattern of volatility spillovers between oil and agricultural markets. In Proceedings of the International Conference-Food in the Bio-based Economy; Sustainable Provision and Access, Wageninge, The Netherlands, 27-29 May 2015.

(C) 2016 by the authors; licensee MDPI, Basel, Switzerland. This article is an open access article distributed under the terms and conditions of the Creative Commons Attribution (CC-BY) license (http://creativecommons.org/licenses/by/4.0/). 